\title{
THE ROLE OF HERBAL ADAPTOGENS AND IMMUNOMODULATORS IN DIETARY FOOD AND PHYTOTHERAPY
}

\author{
Rybak Oksana ${ }^{1}$, Hudz Nataliia ${ }^{1}$, Svidenko Lyudmila ${ }^{2}$, Grygorieva Olga ${ }^{3}$, \\ Makarenko Oleksandr ${ }^{4}$, Brindza Jan ${ }^{5}$
}

\footnotetext{
'Department of Drug Technology and Biopharmaceutics, Danylo Halytsky Lviv National

Medical University, Lviv, Ukraine

${ }^{2}$ Sector of mobilization and saving of herbal resources of the rice Institute of the National Agrarian

Academy of Sciences of Ukraine, Nova Kakhovka, Ukraine

${ }^{3}$ M.M. Gryshko National Botanical Garden of Ukraine of National Academy of Sciences, Kyiv, Ukraine

${ }^{4}$ National University of Food Technologies, Kyiv, Ukraine

${ }^{5}$ Institute of Biodiversity Conservation and Biosafety, Slovak University of Agriculture in Nitra,

Slovak Republic
}

\section{РОЛЬ РАСТИТЕЛЬНЫХ АДАПТОГЕНОВ И ИММУНОМОДУЛЯТОРОВ В ДИЕТИЧЕСКОМ ПИТАНИИ И ФИТОТЕРАПИИ}

\section{Рыбак Оксана, Гудзь Наталия, Свиденко Людмила, Григорьева Ольга, Макаренко Александр, Бриндза Ян}

It was established that phytoadaptogens and immunomodulators are widely used in the composition of dietary food and pharmaceutical products. Phytoadaptogens positively affect the nervous system: normalize the processes of excitation and inhibition in the cerebral cortex, reduce fatigue in physical and mental stress, improve memory, etc. The general adaptogenic action is strengthened by antioxidant and immunomodulating properties of biologically active substances of plant material, bee bread and bee pollen. An analysis of the literature data shows that the immunostimulating and adaptogenic properties of above mentioned natural products are due to the presence phenylpropanoids and polysaccharides. Our attention was focused on a powerful antioxidant and vitamin product with anabolic effect - juice from fruits of Arónia mitschurínii Skvortsov et Maitulina, stimulating the central nervous system - fruits of Schisándra chinénsis (Turcz.) Baill, an immunostimulating agent - Echinácea purpúrea (L.) Moench, and also on bee bread and Lophanthus anisatus Benth. Fruits of chokeberry contain a large amount of B vitamins, phenolic acids and P-vitamin bioflavonoids. Lignan compounds of Schisandra chinensis were reported to possess strong antioxidant activity, which block processes of free radical oxidation and prevent the development of oxidative stress. The most characteristic component of Echinácea purpúrea is chicory acid, which determines the immunomodulation and antiviral activity. Bee pollen and bee bread are rich in polyphenols. We conduct research on the development of food and pharmaceutical products with an adaptogenic and immunostimulating effect on the basis of above mentioned natural products of sector of mobilization and saving of herbal resources of the rice institute of the National Agrarian Academy of Sciences of Ukraine, M.M. Gryshko National Botanical Garden of Ukraine and Institute of Biodiversity Conservation and Biosafety of Slovak University of Agriculture in Nitra.

\footnotetext{
*Corresponding author: Nataliia Hudz, Department of Drug Technology and Biopharmaceutics, Danylo
} Halytsky Lviv National Medical University, Lviv, Ukraine, $\triangle$ natali_gudz@ukr.net 
Keywords: immunocorrectors; bee bread; Arónia mitschurínii; Schisándra chinénsis; Echinácea purpúrea; Lophanthus anisatus

\section{Введение}

Проблема питания наряду с неудовлетворительной экологической ситуацией и большой психоэмоциональной нагрузкой относится к числу факторов, ухудшающих состояние здоровья населения. Существенно возросла роль пищи с низким содержанием витаминов и микроэлементов. Это приводит к ухудшению состояния организма, снижению иммунитета и жизненной активности людей. Поэтому в современных экологических условиях и психоэмоциональной нагрузки большой интерес представляет создание продуктов функционального питания и лекарственных средств растительного происхождения с добавлением адаптогенов и иммуномодуляторов - веществ, способных оказывать регулирующих действие на иммунную систему (Доронин и Шендеров, 2002; Литвинова, 2014; Хасина и Фисенко, 2015; Еремеева и др., 2016; Макиева, 2016; Zhao et al., 2016; Міщенко та ін., 2017; Карнаух и Неплях, 2017). Одной из важных проблем современной фармацевтической технологии и фитотерапии есть увеличение количества отечественных лекарственных средств (Шостак и др., 2014).

Из лекарственных средств, наиболее широко используемых в практике спортивной медицины, используются антигипоксанты, поливитаминные препараты, адаптогены, антиоксиданты, иммунокорректоры, психостимуляторы и др. (Алькевич и др., 2015; Питкевич и др., 2017). Адаптогены привлекают внимание врачей спортивной медицины как средства, способные оптимизировать достижение высокой тренированности и ускорить протекание процессов восстановления спортсменов. Оказывая возбуждающее действие на центральную нервную систему, адаптогены, в отличие от допинговых препаратов, не истощают запасов катехоламинов в депо. В механизме развития фармакологического эффекта адаптогенов важную роль играют также их антиоксидантные свойства (Касьяненко и др., 2011).

По происхождению адаптогены разделяют на синтетические, минеральные, животные и растительные (фитоадаптогены) (Стешенко и др., 2015; Макиева, 2016). Привлекает внимание специалистов спортивной медицины и биологически активные добавки (БАД), содержащие витамины, микроэлементы, фитоадаптогены, иммунокоректоры и антигипоксанты растительного происхождения (плоды и семена лимонника китайского (Schrizandra chinensis (Turcz.) Baill), трава эхинацеи пурпурной (Echinacea purpurea (L.) Moench), корневища и корни элеуторококка колючего (Eleutherococcus senticocus (Rupr. Et Maxim)), остролодочник остролистный (Oxytropis oxyphylla (Pall.) DC.), гребни винограда, корневища и биомасса родиолы розовой (Rhodiola rosea L.), шлемник байкальский (Scutellaria baicalensis Georgi), пчелиная обножка, перга и др. (Касьяненко и др., 2011; Макиева, 2016; Питкевич и др., 2017; Міщенко та ін., 2017).

Фитоадаптогены - метаболические регуляторы, которые повышают возможности организма адаптироваться к внешним стрессовым воздействиям и защищают организм от стрессовых воздействий (стресс-протекторное действие). Механизм действия адаптогенов до сих пор точно не известен. Считают, что они влияют на биосинтез ДНК, РНК, белков, регулируют обмен гормонов, углеводов, липидов, активизируют обменные процессы. Кроме того, адаптогены облегчают приспособление организма к воздействию различных стресс-факторов: перегреванию или переохлаждению, повышенным физическим нагрузкам, недостатку кислорода, ядам, радиации, жажде, голоданию, способны профилактировать многие заболевания или облегчить их течение. Считается, что эффект адаптогенов также связан с их влиянием на работу ЦНС (возбуждающее действие), эндокринной (регулируют функции надпочечников), иммунной и сердечно-сосудистой систем. 
Растительныеадаптогенысодержаттакиебиологическиактивныевеществакакпростыефенолы, флавоноиды, гликозиды, полисахариды, фитостеролы, терпеноиды, гидроксилированные жирные кислоты и гликопептиды.

Вышеперечисленные биологические свойства адаптогенов делают их применение перспективным для оптимизации процессов восстановления работоспособности при интенсивных физических и интеллектуальных нагрузках (Касьяненко и др., 2011; Фомченко и др., 2013; Макиева, 2014; Куркин, 2015; Попков, 2015; Хасина, Фисенко, 2015; Стешенко и др., 2015; Карнаух и Неплях, 2017).

Цель исследования - проведение краткого обзора литературных источников о биологических свойствах некоторых лекарственных растений и природных продуктов для обоснования их введения в новые функциональные диетические продукты и лекарственные средства с адаптогенным и иммуномодулирующим действием.

\section{Материалы и методы}

Анализ литературных данных о растительных адаптогенах и рассмотрение перспективы их использования в создании новых функциональных пищевых продуктов и лекарственных средств с адаптогенным и иммуномодулирующим действием.

\section{Результаты и их обсуждение}

Наиболее высокими адаптогенными свойствами обладают женьшень (Panax ginseng C.A.Mey.), эллеутерокок колючий, лимонник китайский, левзея (Rhaponticum carthamoides (Willd.) Iljin), родиола розовая, аралия маньчжурская и др. В проявлении адаптогенных свойств многих видов лекарственного растительного сырья играют роль такие биологически активные вещества (БАВ) как фенольные и полифенольные соединения (фенольные кислоты, фенологликозиды, лигнаны, флавоноиды), сапонины, экдистероиды, алкалоиды, витамины, полисахариды и др. (Попков, 2015; Стешенко и др., 2015; Макиева, 2016). Общее адаптогенное действие усиливается антиоксидантным, биостимулирующим, иммуномодулирующим, нейротропным свойствами БАВ растительного сырья. Поэтому мы обратили внимание на мощное антиоксидантное и витаминное средство с анаболическим эффектом - плоды аронии черноплодной, стимулирующее ЦНС и тонизирующее средство - плоды лимонника китайского и известное биостимулирующее, иммуностимулирующее средство - эхинацею пурпурную, популярное в китайской медицине растительное средство с иммуностимулирующим и радиопротекторным действием - траву лофанта анисового, а также на пергу (Amico et al., 2013; Семенив и др., 2015; Карнаух и Неплях, 2017).

Широко распространенная «черноплодная рябина», культивируемая во многих странах Восточной и Северной Европы, является аронией Мичурина (Arónia mitschurínii Skvortsov et Maitulina). Часто ее называют аронией черноплодной (Aronia melanocarpa (Michx.), которая естественно произрастает в Северной Америке, где имеет мелкие, малосъедобные плоды и даже относится к трудно искореняемым сорнякам. Арония Мичурина - вид, искусственно созданный в 1890-х году (Скворцов и др., 2005; Виноградова и др., 2014).

Плоды аронии Мичурина благодаря своему богатому химическому составу являются лекарственным сырьём и обладают хорошими пищевыми и лечебно-профилактическими качествами. Плоды содержат большое количество витаминов группы В, фенольных кислот и Р-витаминных биофлавоноидов и их гликозидов: катехинов, флаванонов (гесперидин), флавонолов (кверцетин, рутин), антоцианов и лейкоантоцианов. Среди БАВ также идентифицированы дубильные вещества, пектины, аскорбиновая кислота, органические кислоты, микроэлементы, до 10 \% сахаров (глюкоза, фруктоза, сахароза). Плоды аронии являются одним из самых богатых источников растительных антоцианов, класс флавоноидов, содержащих в качестве агликона антоцианидины. Цианидин-3-О-галактозид, цианидин- 
3-О-арабинозид, цианидин-3-О-ксилозид и цианидин-3-О-глюкозид есть основными полифенольными соединениями плодов аронии и отвечают за темно-красный, синий и фиолетовый цвет плодов. Содержание фенольных соединений колеблется от 40 до 70 мг в 1 г высушенных плодов, из которых 50 \% антоцианы.

Проантоцианидины, антоцианидины и их гликозиды могут находить применение в питании и медицине из-за их высокой антиоксидантной активности и положительного воздействия на здоровье человека при ряде метаболических и иммунных заболеваний, особенно тех, которые связаны с окислительным стрессом, включая сердечно-сосудистые и желудочнокишечные заболевания, рак, нарушения липидов и противовирусную активность (Oszmianski, 1988; Фармакогнозія..., 2015; Еремеева и др., 2016; Cebulak et al., 2017).

Благодаря наличию флавоноидов, а именно рутина арония владеет Р-витаминной активностью: повышает эластичность кровеносных капилляров и нормализирует их проницаемость, имеет антиоксидантные и радиопротекторные свойства (Oszmianski, 1988; Lee et al., 2017). Н.Б. Еремеевой и др. (2016) было рассмотрено влияние условий сверхкритической экстракции на антиоксидантные свойства получаемых экстрактов и установлено, что антиоксидантная активность увеличивается с повышением температуры экстракции. Полезные свойства аронии также обусловлены содержанием в ней витаминов A, C, B, B , E, Р, РP, каротина, марганца, меди, бора, магния, молибдена, железа (Формазюк, 2003; Орловецкая и Данькевич, 2014).

Вплодахарониисодержитсямногойода,поэтомуониполезныпридиффузномтоксическомзобе. Благодаря содержанию пектиновых веществ арония способствует выведению из организма тяжелых металлов и радиоактивных веществ. Пектины нормализуют функционирование кишечника, устраняют спазмы и оказывают желчегонный эффект. В мякоти ягод найдены также амигдалин, кумарин и другие соединения (Орловецкая и Данькевич, 2014).

Растительные средства из плодов аронии имеют гипотензивное, спазмолитическое, противовоспалительное, капилляроукрепляющее, мочегонное, желчегонное и др. действие. Сок аронии является компонентом биогенного стимулятора Биоарон С (Лекарственные растения..., 1991; Формазюк, 2003; Липкан, 2006; Фармакогнозія..., 2015; Державний реєстр..., 2017). П.Н. Попковым (2015) разработан фитоадаптогенный бальзам на основе 32 видов лекарственного растительного сырья, в состав которого вошли корневища с корнями эхинацеи пурпурной как иммуностимулирующего средства и плоды аронии черноплодной как мощного антиоксидантного средства. Д.Б. Семенив и др. $(2014,2015)$ установили гипоазотемическое, гепатопротекторное и анаболическое действие сока аронии и анаболический эффект масла аронии. Анаболический эффект обеспечивается усилением синтеза нуклеиновых кислот в печени и общего белка в организме.

Плоды и семена лимонника китайського (Schizandra chinensis (Turcz.) Baill)используются как лекарственное сырье, остальные части растения не подлежат заготовке (Мальцева и др., 2015; Макиева, 2016; Государственный реестр..., 2017; Державний реєстр..., 2017). Плоды и семена содержат лигнаны (схизандрин, дезоксисхизандрин, гомизин, схизандрол и др.), фенольные соединения, флавоноиды (катехины, антоцианы), органические кислоты (аскорбиновая, лимонная, яблочная), дубильные вещества, жирные и эфирные масла, пектины, сахара. Лимонник китайский обладает выраженным стимулирующим эффектом, сопоставимым с действием допинговых препаратов (Фармакогнозія..., 2015; Формазюк, 2003; Липкан, 2006; Жукович и др., 2007; Мальцева и др., 2015; Лекарственные растения, 2016; Макиева, 2016; Zhao et al., 2016; Питкевич и др., 2017).

Свойства данного растения укреплять иммунитет и действовать, как мощный адаптоген были известны давно и широко использовались в восточной медицине, в частности в Китае. Благодаря лигнанам, которые находятся в ягодах лимонника, организм быстрее и легче адаптируется к новой окружающей среде, климату, смене погоды и часовых поясов. Ученые отмечают, что регулярный прием экстракта лимонника усиливает иммунитет, повышает 
сопротивляемость ко многим болезням, укрепляет адаптивные возможности организма (Asea et al., 2013; Кондакова и др., 2016; Zhao et al., 2016; Макиева, 2016; Карнаух и Неплях, 2017).

В России семена лимонника используют для промышленного производства настойки, применяемой в качестве средства, для лечения астенического синдрома, переутомления, психического и физического перенапряжения, повышения работоспособности организма, нейроциркуляторной дистонии по гипотоническому типу, комплексной терапии ослабления половой функции на почве неврастении (Государственный реестр..., 2017).

Лимонник повышает стойкость организма к различным нагрузкам, улучшает регулирование физиологических процессов, является сильным антиоксидантным средством, нормализирует артериальное давление, улучшает пищеварение, используется как средство профилактики гриппа и других инфекционных заболеваний. Препараты лимонника повышают чувствительность периферического и центрального зрения (Энциклопедический словарь..., 1999; Кротова и Ефремов, 1999; Формазюк, 2003; Липкан, 2006; Добрина и др., 2016). Исследования последних лет доказали гепатопротекторную, онкопротекторную, антивирусную, актопротекторную, антиоксидантную активность препаратов лимонника китайского и индивидуальных веществ, выделенных из него, доказали их положительное влияние на углеводный обмен. Следует отметить, что стимулирующий эффект препаратов лимонника тесно связан с антиоксидантным действием лигнанов, блокирующих процессы свободнорадикального окисления и предотвращающими развитие оксидантного стресса (Zhao et al., 2016; Макиева, 2016).

Лечебный эффект от применения препаратов лимонника китайского распространяется практически на все внутренние органы, что обуславливает использование этих препаратов для лечения широкого спектра заболеваний (Добрина и др., 2016).

Рядработ посвящен фармакологической оценке различныхпрепаратовлимонника, в частности, подробно изучено действие экстрактов семян лимонника на центральную нервную систему, имеются указания на применение лимонника в психиатрии, указывается на возможность применения плодов лимонника при производстве безалкогольных напитков, в кондитерской и других отраслях пищевой промышленности (Кротова и Ефремов, 1999).

K наиболее распространенным и широко изученным растением относится эхинацея пурпурная (Echinácea purpúrea (L.) Moench. Она обладает выраженными иммуностимулирующим, противовоспалительным, противовирусным, антибактериальным и антиоксидантным свойствами (Фомченко и др., 2013; Литвинова, 2014; Куркин, 2015). При изучении фитоиммуностимуляторов на рынке Украины установлено, что наиболее многочисленной группой есть группалекарственныхсредств на основеэхинацеи (Міщенкотаін., 2017). Мета-анализ клинических исследований подтвердил, что профилактическое применение препаратов эхинацеии пурпурной снижает на 55 \% частоту риновирусныхинфекций (Литвинова, 2014). Химический анализ растений рода Echinacea Moench позволил обнаружить следующие соединения, обладающие фармакологической активностью: полисахариды, в том числе иммуноактивные; флавоны и флавонолы (лютеолин, кемпферол, рутин, кверцетин и др.); производные кофейной кислоты (эхинакозид, цинарин, цикориевая кислота); гликопротеины, включая лектины; алкалоиды; сапонины; алкиламиды ненасыщенных кислот; дубильные вещества пирокатехиновой природы (5 - 11 \%); органические кислоты; витамины; эфирные масла (борнеол, борнилацетат, фарнезен); макро- и микроэлементы: кальций, калий, алюминий, магний,хлор,железо,молибден,селен, марганец,серебро идр.; фитостеролы;цианидины;смолы. Наиболее характерный компонент - цикориевая кислота (2,3-О-дикофеилтартаровая кислота) обусловливающая иммуномодулирующую и противовирусную активность (Фармакогнозія..., 2015; Куркин, 2015; Хасина и Фисенко, 2015). Известно, что эхинацея пурпурная богата на сбалансированный по незаменимым аминокислотам белок и способна компенсировать в рационе животных недостаток биологически активних веществ (Фомченко и др., 2013). 
Этанольные экстракты свежего растения показали наивысшую активность непосредственно связанную с более высоким содержанием фенольных соединений (229,22 мг эквивалентов галловой кислоты (GAE/мл), флавоноидов (124,83 мг GAE/мл), органических кислот (8,89 г/100 г) и токоферолов (4,55 мг/100 г) (Pires et al., 2016).

Назначение животным с экспериментальным зобом и ортодонтической моделью перемещения зубов предлагаемого комплекса препаратов (йодид калия, эхинацея композитум С, терафлекс), предупреждало развитие воспалительных реакций, повышало антиоксидантную защиту и неспецифическую резистентность организма. Установленные эффекты проявлялись только при поэтапном применении препаратов комплекса и были гораздо менее выражены при монотерапии, что свидетельствует о потенцирующем влиянии препаратов комплекса с эхинацеей (Колесник и др., 2013).

Препараты эхинацеи пурпурной целесообразно применять в профилактической медицине в качестве фармакологического средства для поддержания биоэнергетических процессов на оптимальном уровне и повышения физической работоспособности в условиях экстремального холодового воздействия. Влияние эхинацеи пурпурной на физическую работоспособность при экстремальном действии холода (Хасина и Фисенко, 2015).

К числу природных иммуностимуляторов с увеличением фагоцитарной активности нейтрофилов Т- и В-лимфоцитов, и адаптогенов некоторые авторы относят и продукты пчеловодства (обножка и перга). Такое биологическое действие объясняется в основном их белковым составом и антиоксидантными свойствами. Было установлено на лабораторных животных, что обножка способствует увеличению массы тела и повышает содержание гемоглобина.

Обножка может применяться для восстановления энергетических затрат при спортивных соревнованиях, а также напряженной умственной работе (Касьяненко и др., 2011; Hudz et al., 2017).

В научной медицине в фитопрепаратах иммуностимулирующего и радиопротекторного действия, а также выводящих радионуклиды из организма применяется лофант анисовый (Lophanthus anisatus Benth.). В надземной части растения содержатся макро- и микроэлементы: магний, кальций, фосфор, азот, железо, цинк, медь, никель, кобальт, свинец, бор, кадмий, флавоноиды (акацетин, менарин агастиходин), а также эфирное масло (Либусь и др., 2004). Эфирное масло лофанта анисового оказывает противовоспалительное, обезболивающее, противосудорожное, противоспазматическое, иммуностимулирующее, радиопротекторное, стимулирующее кроветворение, противомикробное действие. В эфирном масле идентифицированы такие компоненты как метилхавикол (63,5\%), пулегон (15 - $23 \%)$, лимонен (от 2,7 до 5\%), ментон (2,3\%), изоментон (от 6,4 до 16,3 \%), анисовый альдегид (3,0 \%), р-метоксикоричный альдегид (2,0%) и другие терпеноиды (Работягов и Курдюкова, 2008).

Лофант анисовый находит широкое применение в китайской медицине при болезнях желудка и кишечника и в качестве улучшающего пищеварение средства. Настои из цветущей надземной части растения применяют при простуде, болезнях крови и как жаропонижающее средство. В монгольской медицине надземную часть растения употребляют для регулирования обмена веществ, как общеукрепляющее и предупреждающее старенне средство (Либусь и др., 2004).

Флавоноиды, имеющиеся в надземной части растения, обуславливают неспецифическую противоопухолевую активность галеновых препаратов лофанта. Галеновые препараты лофанта (чаи, отвары, настои и экстракты)оказывают успокаивающее действие на центральную нервную систему и обладают противосудорожным действием. Настой цветков применяется внутрь и наружно при параличах (в частности лицевого нерва) и невралгиях (Эфиромасличные культуры..., 1998). Тонкий приятный аромат растения хорошо сочетается с фруктовыми салатами и сладкими пудингами. Изысканный аромат приобретают сдобренные 
лофантом компоты из слив, алычи, различных сортов яблок, груш и черешни. Растение и его эфирное масло входят в композиции чайных напитков (Кораблева, 2011).

\section{Выводы}

Анализ литературых данных показывает, что иммунотропные и адаптогенные свойства растительных средств обусловлены наличием в них фенилпропаноидов и полисахаридов (лимонник китайский, арония Мичурина, эхинацея пурпурная, перга, пчелиная обножка). Способность фитосредств повышать резистентность и выносливость организма есть последствием их антиоксидантного и мембраностабилизирующего действия, которое характерно для фенольных соединений. Результаты проведенного литературного обзора могут служить обоснованием для разработки новых функциональных диетических продуктов и лекарственных средств с иммуномодулирующеми и адаптогенными свойствами на основе рассмотренных нами видов лекарственного растительного сырья и природных продуктов. Нами проводятся исследования по разработке продуктов питания и лекарственных средств с адаптогенным и иммуностимулирующим эффектом на основе сырья Сектора мобилизации и сохранения растительных ресурсов Института риса Национальной аграрной академии наук Украины, Национального Ботанического сада им. Н.Н. Гришко и Института сохранения биоразнообразия и биобезопасности Словацкого аграрного университета в Нитре (Hudz et al., 2017).

\section{Acknowledgments}

The publication was prepared with the active participation of researchers involved in the International network AgroBioNet of the Institutions and researchers for realization of research, education and development program «Agrobiodiversity for improving nutrition, health and life quality» and within the project ITMS 25110320 104. Co-author Nataliia Hudz thanks to the International Visegrad Fund for scholarship and research internships, during which were got the results and knowledge presented in this paper.

\section{Литература}

Asea, A., Kaur, P., Panossian, A., Wikman, K.G. 2013. Evaluation of molecular chaperons Hsp72 and neuropeptide $Y$ as characteristic markers of adaptogenic activity of plant extracts. Phytomedicine, vol. 20(14), p. 1323-1329. DOI: 10.1016/j.phymed.2013.07.001.

Cebulak, T., Oszmiański, J., Kapusta, I., Lachowicz, S. 2017. Effect of UV-C Radiation, Ultra-Sonication Electromagnetic Field and Microwaves on Changes in Polyphenolic Compounds in Chokeberry (Aronia melanocarpa). Molecules, vol. 22(7), p. 1-16. DOI: 10.3390/molecules22071161

Hudz, N., Ivanova, R., Brindza, J., Grygorieva, O., Schubertová. Z., Ivanišová, E. 2017. Approaches to the determination of antioxidant activity of extracts from bee bread and safflower leaves and flowers. Potravinarstvo Slovak Journal of Food Sciences, vol. 11, no. 1, p. 480-488. DOI: https://dx.doi. org/10.5219/786

Oszmianski, J., Sapis, J.C. 1988. Anthocyanins in fruits of Aronia melanocarpa (chokeberry). J. Food Sci., vol. 53, p. 1241-1242.

Pires, C., Martins, N., Carvalho, A.M., Barros, L., Ferreira, I.C. 2016. Phytopharmacologic preparations as predictors of plant bioactivity: A particular approach to Echinacea purpurea (L.) Moench antioxidant properties. Nutrition, vol. 32(7-8), p. 834-839. DOI: 10.1016/j.nut.2016.01.005

Zhao, X., Liu, C., Xu, M., Li, X., Bi, K., Jia, Y. 2016. Total Lignans of Schisandra chinensis Ameliorates Aß1-42Induced Neurodegeneration with Cognitive Impairment in Mice and Primary Mouse Neuronal Cells. PLoS One, vol. 11, no. 4, p. e0152772. https://doi.org/10.1371/journal.pone.0152772 Алькевич, Е.Л., Стаценко, Е.А., Трухачева, Т.В. 2015. Антиоксидантная активность адаптогенов, применяемых 
в спортивной практике. [Эллектронний ресурс]. Режим доступа: file:///C:/Users/Acer/AppData/ Local/Temp/2013010313493137.pdf

Державний реєстр лікарських засобів України. 2017. [Эллектронний ресурс]. Режим доступа: http:// www.drlz.com.ua/

Виноградова, Ю., Куклина, А., Бриндза, Я., Григорьева, О. 2014. Aronia mitschurinii A. Skvorts. et Maitul. - плодовое и лекарственное растение. Zborník výsledkov a príspevkov z riešenia výskumného projektu Podpora inovácie technológií špeciálnych výrobkov biopotravín pre zdravú výživu ludí ITMS 26220220115, c. 278-290. ISBN 978-80-552-1272-2.

Государственный реестр лекарственных средств Российской Федерации. 2017. [Эллектронний ресурс]. Режим доступа: https://grls.rosminzdrav.ru/grls. aspx?s=\%D0\%BB\%D0\%B8\%D0\%BC\%D0\%BE\%D0\%BD\%D0\%BD\%D0\%B8\%D0\%BA

Добрина, Ю.В., Мальцева, А.А., Сорокина, А.А., Сливкин, А.И. 2016. Изучение химического и элементного состава листьев лимонника китайского, заготовленных в Воронежской области. Вестник ВГУ, Серия: Химия. Биология. Фармачія, № 1, с. 136-139.

Доронин, А.Ф., Шендеров, Б.А. 2002. Функциональное питание. М.: Гранть. 296 с.

Еремеева, Н.Б., Макарова, Н.В., Платонов, И.А. 2016. Антиоксидантная активность экстрактов черноплодной рябины, полученных в надкритических условиях. Техника и технология пищевых производств, т. 42, № 3, с.12-18.

Жукович, Е.Н. и др. 2007. К исследованию биологически активных лигнанов настойки и семян лимонника китайского. Химико-фрармачевтический журнал, т. 41, №2, с. 35-37.

Карнаух, Э.В., Неплях, А.В. 2017. Повышение качества жизни студентов - фармакология памяти и адаптивности организма [Эллектронний ресурс]. Режим доступа: https: //sjes.esrae.ru/ pdf/2017/1/399.pdf

Колесник, К.А., Деньга, О.В., Макаренко, О.А. 2013. Влияние адаптогенного комплекса на состояние неспецифической резистентности организма при ортодонтическом перемещении зубов на фоне экспериментального зоба [Эллектронний ресурс]. Режим доступа: www. csmu.edu.ua /res/200917/ Tmbv_2013_16_1(3)_23.pdf\#page=3\&zoom=auto,-13,298

Кондакова, В.В., Готовский, Д.Г., Фомченко, И.В. 2016. Применение растительного адаптогена для повышения защитных свойств организма животных. Вісник аграрної науки Причорномор'я, вип. 2, № 1, c. 173-181. http: //nbuv.gov.ua/UJRN/vanp_2016_2(1)_23

Кораблева, О.А. 2011. Пряности и приправы. К.: Юнивест Медиа. 196 с.

Кротова, И.В., Ефремов, А.А. 1999. Исследование химического состава плодов лимонника китайского. Химия растительного сырья, № 4, с. 131-133.

Куркин, В.А. 2015. Фенилпропаноиды как важнейшая группа биологически активных соединений лекарственных растений.Международныйжурнал прикладныхи фундаментальныхисследований, № 12 (7), с. 1338-1342.

Лекарственные растения мировой флоры: энциклопед. 2016. Справочник. Н.В. Попова, В.И. Литвиненко, А.С. Куцанян. Харьков: Діса плюс. 540 с.

Лекарственные растения: Справ. Пособие 1991. Под ред. Н.И. Гринкевич. М.: Высш. шк. 398 с.

Касьяненко, В.И., Дубцова, Е.А., Комиссаренко, И.А. 2011. Лечебное действие пыльцы (обножки) и перги при недостаточности питания, метаболическом синдроме и гепатитах неуточненной этиологии. Экспериментальная и клиническая гастроэнтерология, № 11, с. 53-58.

Либусь,О.К.,Работягов,В.Д.,Кутько,С.П.,Хлыпенко,Л.А.2004.Эфирномасличныеипряноароматические растения. Херсон, «Айлант». 272 с.

Липкан, Г.Н. 2006. Витаминные растения в медицине. Киев: ЧП Балюк И.Б. 626 с.

Литвинова, Е.В. 2014. Клинико-фармакологические аспекты и фармакоэкономика препаратов на основе эхинацеи пурпурной. Фітотерапія, № 4, с. 67-71. 
Макиева, М.С. 2016. Фармакотехнологические исследования дерматологических композиций с использованием лимонника китайского семян $\mathrm{CO}_{2}$ - экстракта: дис. ... канд. фармац. Наук. Пятигорск. 120 с.

Мальцева, А.А., Тамилина, И.А., Недосекова, М.А., Тринеева, О.В., Сливкин, А.И., Чистякова, А.С. 2015. Изучение лигнанов в листьях лимонника методом ТСХ. Вестник ВГУ, Серия: Химия. Биология. Фармачия, № 1, с. 147-151.

Міщенко, О.Я., Зайченко, Г.В., Халєєва, О.Л., Шаріфов, Х.Ш. 2017. Аналіз асортименту фітостимуляторів на фармацевтичному українському ринку. Фармакоекономіка в Україні: стан та перспективи розвитку: зб. наук. праць дев'ятій наук.-практ. інтернет-конф. Х. : Вид-во НФаУ, с. 88-93.

Орловецкая, Н.Ф., Данькевич, О.С. 2014. Использование аронии черноплодной в современной медицине. Теоретичні та практичні аспекти дослідження лікарських рослин: матеріали І Міжнар. наук.-практ. internet-конф. Х.: НФаУ, с. 125-126.

Питкевич, Э.С., Крестьянинова, Т.Ю., Деркач, И.Н. 2017. Пути фармакологической коррекции работоспособности в спорте [Эллектронний ресурс]: Эллектронные данные. Режим доступа: http://www.gsmu.by/file/konferen/stress/5/pit.pdf

Попков, П.Н. 2015. Получение фитоадаптогенных бальзамов на основе растительного сырья [Эллектронний ресурс]: Эллектронные данные. Режим доступа: https://www.science-education. ru/pdf/2015/1/704.pdf

Работягов, В.Д., Курдюкова, О.Н. 2008. Ароматические растения, их эфирные масла и бальзамы. Справочное пособие. Луганск: изд-во «Шико», ООО «Виртуальная реальность». 295 с.

Семенів, Д.В. 2014. Дослідження гепатопротекторних властивостей субстанцій аронії чорноплідної. Проблеми екологічної та медичної генетики і клінічної імунології, № 1, с. 161-165.

Семенів, Д.В., Бєлік, Г.В., Куценко, Т.О., Столєтов, Ю.В. 2015. Вивчення впливу субстанцій аронії чорноплідної на білковий обмін. Ukrainian biopharmaceutical Journal, № 5 (40), с. 37-42.

Стешенко, О.М., Арсеньєва, Л.Ю., Ройко, О.Ю., Паламарчук, О.П. 2015. Дослідження фенольних сполук рослинних адаптогенів з метою внесення до рецептури функціональних харчових продуктів. Науковий вісник ЛНУВМБТ імені С.3. Гжицького, т. 17, № 4 (64), с. 130-136.

Фармакогнозія: базовий підручн. для студ. вищ. фарм. навч. закл. (фарм. ф-тів) IV рівня акредит. 2015. В.С. Кисличенко, І.О. Журавель, С.М. Марчишин [та ін.]. Х.: НфаУ: Золоті сторінки. 736 с.

Фомченко, И.В., Готовский, Д.Г., Кондакова, В.В. 2013. Использование растительного биостимулятора для повышения адаптивных свойств организма животных и птиц. Аграрний вісник Причорномор'я. Ветеринарні науки, вип. 68, с. 280-285. http://nbuv.gov.ua/UJRN/ avpvet_2013_68_55

Формазюк, В.И.2003. Энциклопедия пищевых лекарственных растений: Культурные и дикорастущие растения в практической медицине. К.: Издательство А.С.К. 792 с.

Хасина, Э.И., Фисенко, В.М. 2015. Влияние эхинацеи пурпурной на физическую работоспособность при экстремальном действии холода. Тихоокеанский медицинский журнал, № 2, с. 55-57.

Шостак, Т.А., Калинюк, Т.Г., Гудзь, Н.І. 2014а. Застосування рослинних субстанцій в якості активних фармацевтичних інгредієнтів. Фітотерапія, № 3, с. 63-65.

Энциклопедический словарь лекарственных растений и продуктов животного происхождения:Учеб. Пособие. 1999. Под ред. Г.П. Яковлева и К.Ф. Блиновой. СПб.: Специальная Литература. 407 с.

Эфиромасличные культуры и пряноароматические растения для использования в фитотерапии. 1998. Сост. Работягов В.Д., Бакова Н.Н., Хлыпенко Л.А., Голубева Т.Ф. - Ялта. 82 с. 